\title{
Social and racial inequalities in COVID-19 risk of hospitalisation and death across São Paulo state, Brazil
}

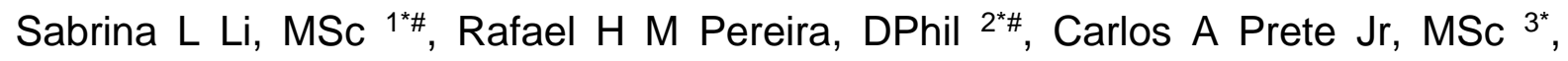
Alexander E Zarebski, PhD ${ }^{4}$, Lucas Emanuel, PhD ${ }^{2}$, Pedro JH Alves, MSc ${ }^{2}$, Pedro S Peixoto ${ }^{5}$, PhD, Carlos KV Braga, MSc ${ }^{2}$, Andreza A de Souza Santos, PhD ${ }^{6}$, William M de Souza, PhD ${ }^{4,7}$, Rogerio J Barbosa, PhD ${ }^{8}$, Lewis F Buss, MD ${ }^{9}$, Alfredo Mendrone Jr, MD 10, Cesar de Almeida-Neto, MD 10,11, Suzete C Ferreira, PhD 10,12, Nanci A Salles, BSc 10,12, Izabel Marcilio, MD 13, Chieh-Hsi Wu, PhD 14, Nelson Gouveia, MD ${ }^{15}$, Vitor H Nascimento, $\mathrm{PhD}^{3}$, Ester C Sabino, MD ${ }^{9}$, Nuno R Faria, PhD 4,9,16, Jane P Messina, PhD 1,17

1. School of Geography and the Environment, University of Oxford, Oxford, United Kingdom.

2. Institute for Applied Economic Research, Brasília, Brazil.

3. Department of Electronic Systems Engineering, University of São Paulo, São Paulo, Brazil.

4. Department of Zoology, University of Oxford, Oxford, United Kingdom.

5. Department of Applied Mathematics, Institute of Mathematics and Statistics, University of São Paulo, São Paulo, Brazil.

6. Oxford School of Global and Area Studies, Latin American Centre, University of Oxford, Oxford, United Kingdom.

7. Virology Research Center, University of São Paulo, Ribeirão Preto, Brazil.

8. Center for Metropolitan Studies, Faculty of Philosophy, Languages and Literature, and Human Sciences, University of São Paulo, São Paulo, Brazil.

9. Departamento de Molestias Infecciosas e Parasitarias \& Instituto de Medicina Tropical da Faculdade de Medicina da Universidade de São Paulo, São Paulo, Brazil. 10. Fundação Pró-Sangue Hemocentro de São Paulo 11. Disciplina de Ciências Médicas, Faculdade de Medicina da Universidade de São Paulo, São Paulo, Brazil. 
12. Laboratory of Medical Investigation in Pathogenesis and Directed Therapy in Onco - Immuno - Hematology (LIM-31) HCFMUSP, University of São Paulo Medical School, São Paulo, Brazil.

13. Epidemiologic Surveillance Center, Hospital das Clinicas - University of São Paulo Medical School, São Paulo, Brazil.

14. Mathematical Sciences, University of Southampton, Southampton, United Kingdom.

15. Department of Preventive Medicine, University of São Paulo Medical School

16. MRC Centre for Global Infectious Disease Analysis, J-IDEA, Imperial College London, London, UK.

17. Oxford School of Global and Area Studies, University of Oxford, Oxford, United Kingdom.

44

45 *These authors contributed equally.

\#Corresponding authors:

1. Sabrina L. Li, School of Geography and the Environment, University of Oxford, South Parks Rd, Oxford, OX13QY, United Kingdom. E-mail: sabrina.li@ouce.ox.ac.uk

2. Rafael H.M. Pereira, Institute for Applied Economic Research (Ipea), SBS Quadra 1 - Bloco J - Ed. BNDES - CEP: 70076-900 - Brasília - DF - Brasil. E- 


\section{Summary}

60 Background: Little evidence exists on the differential health effects of COVID-19 on 61 disadvantaged population groups. Here we characterise the differential risk of 62 hospitalisation and death in São Paulo state, Brazil and show how vulnerability to 63 COVID-19 is shaped by socioeconomic inequalities.

64 Methods: We conducted a cross-sectional study using hospitalised severe acute 65 respiratory infections (SARI) notified from March to August 2020, in the Sistema de 66 Monitoramento Inteligente de São Paulo (SIMI-SP) database. We examined the risk 67 of hospitalisation and death by race and socioeconomic status using multiple datasets 68 for individual-level and spatio-temporal analyses. We explained these inequalities 69 according to differences in daily mobility from mobile phone data, teleworking 70 behaviour, and comorbidities.

71 Findings: Throughout the study period, patients living in the $40 \%$ poorest areas were 72 more likely to die when compared to patients living in the $5 \%$ wealthiest areas (OR: $731.60,95 \% \mathrm{Cl}: 1.48-1.74)$ and were more likely to be hospitalised between April and 74 July, 2020 (OR: 1.08, 95\% Cl: 1.04 - 1.12). Black and Pardo individuals were more 75 likely to be hospitalised when compared to White individuals (OR: 1.37, 95\% Cl: 1.32 $76-1 \cdot 41$; OR: $1 \cdot 23,95 \% \mathrm{Cl}: 1 \cdot 21-1 \cdot 25$, respectively), and were more likely to die (OR: 1.14, 95\% Cl: $1 \cdot 07-1 \cdot 21 ; 1 \cdot 09,95 \% \mathrm{Cl}: 1 \cdot 05-1 \cdot 13$, respectively).

78 Interpretation: Low-income and Black and Pardo communities are more likely to die 79 with COVID-19. This is associated with differential access to healthcare, adherence 80 to social distancing, and the higher prevalence of comorbidities.

\section{Funding:}

82 This project was supported by a Medical Research Council-São Paulo Research 83 Foundation (FAPESP) CADDE partnership award (MR/S0195/1 and FAPESP 84 18/14389-0) (http://caddecentre.org/). This work received funding from the U.K. 85 Medical Research Council under a concordat with the U.K. Department for 86 International Development. 
medRxiv preprint doi: https://doi.org/10.1101/2020.12.09.20246207; this version posted December 13, 2020. The copyright holder for this preprint (which was not certified by peer review) is the author/funder, who has granted medRxiv a license to display the preprint in perpetuity.

It is made available under a CC-BY-ND 4.0 International license .

\section{Introduction}

89 The COVID-19 pandemic has amplified the effects of social inequalities on exposure

90 and death in low socioeconomic groups ${ }^{1}$, particularly in Brazil, where it has caused

91 significant mortality ${ }^{2}$. Few studies have addressed the uneven impact of COVID-19

92 by socioeconomic status and race ${ }^{3-5}$, especially in low and middle-income countries,

93 in part because national surveillance systems seldom collect or report this information

$94{ }^{6}$. In Brazil, higher risk of COVID-19 death has been found for Black and Pardo (mixed

95 ethnicity) Brazilians ${ }^{7}$. Nonetheless, there is still little information on how the differential

96 health outcomes of COVID-19 are shaped by broader social inequalities that

97 determine the capacity to adhere to social distancing and non-pharmaceutical

98 interventions (NPIs).

99 It is paramount to understand the potential social drivers of COVID-19 morbidity and 100 mortality, particularly in countries with high inequality such as Brazil ${ }^{8}$. The first COVID10119 cases in Brazil were detected in São Paulo ${ }^{9}$, the most populous state and home 102 to diverse racial groups. In the Brazilian context of politically polarised public health 103 responses ${ }^{10}$, São Paulo has been severely affected by COVID-19 ${ }^{11}$ and access to 104 testing has been limited for low-income populations ${ }^{12}$. By combining multiple high105 resolution data sources, we conducted a multi-scale analysis to investigate the risk of 106 hospitalisation and death from severe acute respiratory infections (SARI), 107 predominantly caused by COVID-19 ${ }^{12}$, by race and socioeconomic status in the state 108 of São Paulo. We examined potential drivers of these inequalities by evaluating local 109 levels of population adherence to social distancing, access to teleworking, and 110 prevalence of comorbidities 


\section{Methods}

\section{Data Sources}

\section{Severe acute respiratory infections (SARI) and patient information}

114 Patient-level information on demographic characteristics, home address, 115 hospitalisation, and health outcomes were collected from the São Paulo State Health 116 Secretariat SARI hospitalisations database (SIMI-SP) ${ }^{13}$. SARI can be caused by 117 SARS-CoV-2 and is defined by the Brazilian Ministry of Health as flu-like syndrome 118 plus one of the following: dyspnoea, persistent chest pain, or hypoxia. All SARI cases 119 and deaths are notified in the SIMI-SP database, regardless of hospitalisation.

120 We included all SARI related hospitalisations and deaths notified in São Paulo state 121 between March 15 and August 29, 2020. Given that recent data is incomplete due to 122 reporting delays ${ }^{14}$ and to avoid biases, we limited our analysis to patients with 123 symptoms onset between these dates (epidemiological weeks $10-35$ ) (figure 1B). 124 We also included SARI cases with unknown aetiology, as those are likely related to 125 COVID-19 but not lab-confirmed due to low rates of COVID-19 testing in Brazil ${ }^{15}$ and 126 socioeconomic bias in testing ${ }^{12}$.

127 Zip code information was only available for cases reported in São Paulo state. Data 128 was geocoded using the patient's self-reported home address or postal code with 129 Galileo (www.img.com.br) and Google API. Information on the health facility where 130 each case was notified was linked to the National Registry of Health Facilities (CNES), 131 which includes information on the mode of health care provision (public and private).

132 The race of patients was partially self-declared and partially identified by a health 133 professional. Race was categorised as either "White", "Black", "Asian" (East or 134 Southeast Asian), "Pardo" (mixed ethnic ancestries with diverse skin colours) ${ }^{16}$ or 135 Indigenous. Race information was missing for $53480(23.9 \%)$ of retrieved SARI 136 cases, and were imputed using the racial distribution of the census tract of residence 137 (see Supplementary Appendix A for details). About $0 \cdot 1 \%$ of the population in São 
138 Paulo self-identified as indigenous ${ }^{17}$ and since only 166 indigenous patients (0.07\%)

139 were recorded, they were not considered in our analysis.

\section{Socioeconomic data}

141 We obtained data on municipality-level socioeconomic factors from the latest 142 population census (2010) compiled by the Brazilian Institute of Geography and 143 Statistics (IBGE). We selected household income per capita, population density, and 144 income inequality (Gini Index). We also determined the proportion of residents with a 145 primary education or lower, employment-to-population ratio, and the proportion of the 146 working population without a formal labour market contract or social security. The road 147 network distance from the centroid of each census tract to the nearest healthcare 148 facility was computed considering all facilities that hospitalised SARI patients via the 149 public healthcare system (SUS). Information on employment status and comorbidities 150 during the epidemic was retrieved from the National Household Sample Survey 151 (PNAD COVID-19), a national telephone survey conducted by IBGE with over 1888 152560 interviews between May and September 2020. Details are described in 153 Supplementary Appendix A.

\section{Daily mobility and non-pharmaceutical interventions}

155 To assess local-level adherence to social distancing, we used daily mobile phone data 156 provided by In-Loco (https://www.inloco.com.br/covid-19) ${ }^{18}$ for the Região 157 Metropolitana de São Paulo (greater metropolitan area of São Paulo: RMSP). This 158 data was aggregated using a hexagonal grid based on the global H3 index at 159 resolution 8 . Each cell has an edge of approximately 460 meters and an area of 0.74 $160 \mathrm{~km}^{2}$ (https://h3geo.org/docs/core-library/restable). For each H3 cell, the social 161 isolation index was measured as the number of people who did not leave their cell of 162 residence during the day, divided by the number of residents in that cell. Each mobile 163 phone was assigned to an $\mathrm{H} 3$ cell based on the owner's location of residence during 164 the evening and their previous travel history. The racial composition and income level 165 of each cell were determined using dasymetric interpolation (Supplementary Appendix 166 A). 
167 We also used municipality and state-level data on NPIs from a continuous survey 168 conducted between May 13 and July 31, $2020{ }^{19}$. The survey had 13 questions related 169 to the implementation and easing of social distancing measures, and responses were 170 obtained from 612 mayors in São Paulo (94.8\% of the total).

171 Data analysis

\section{Probability of hospitalisation and death}

173 We conducted an individual-level analysis to estimate the probability of reporting a 174 SARI hospitalisation given a patient's race and average income level in their census 175 tract of residence. Census tracts were grouped by quantiles of income per capita into 176 six categories as presented in the results. Similarly, we determined the probability of 177 death from SARI given a patient's race, income, and administrative type of the health 178 facility where the patient was hospitalised (public or private). Both probabilities were 179 standardised by age and sex to account for demographic differences between groups. 180 They were calculated for every month between March and August 2020. Probabilities 181 for each age-sex group were estimated empirically using relative frequencies. Odds 182 ratios using White patients and the highest income level as reference groups were 183 computed. Confidence intervals were calculated using bootstrapping. Details are in 184 Supplementary Appendix A.

\section{Seroprevalence by socioeconomic status}

186 To assess the broader risk of SARS-CoV-2 infection beyond hospitalisation, we 187 analysed seroprevalence data collected as part of the national Covid-IgG study ${ }^{20}$ from 188 blood donors aged 16 - 69 living in São Paulo city 20 (Supplementary Appendix A). 189 We calculated the proportion of individuals by education and race category with 190 detectable anti-SARS-CoV-2 antibodies between February and October 2020.

\section{Socioeconomic drivers and hospitalisation risk}

192 An ecological spatio-temporal regression analysis was conducted at the municipality 193 level for São Paulo state ( $n=645$ municipalities) to assess the monthly risk of 
194 hospitalisation and its association with socioeconomic factors between March 1 and

195 August 29, 2020. To further understand the association between socioeconomic 196 conditions and COVID-19 risk, we conducted the same analysis at the census tract 197 level ( $n=30$ 815) for the RMSP, where the majority of cases were concentrated. The 198 relative risk of hospitalisation was estimated using a hierarchical Bayesian model 199 composed of a generalised log-linear model with spatially structured and unstructured 200 random effects to account for spatial autocorrelation and time-varying random effect. 201 The spatial structure is characterised by population movement between municipalities 202 from March 1 to August 15, 2020 defined by In-Loco mobile geo-location data 203 summarised elsewhere ${ }^{18}$. A detailed description of the model and interpretation, 204 covariates, and diagnostics can be found in Supplementary Appendix A.

\section{Social adherence response to NPIs}

206 We used an event study design ${ }^{21}$ to examine how different socioeconomic groups 207 changed their daily mobility levels in response to the introduction and relaxation of 208 NPIs in the RMSP. We compared changes in mobility patterns of the population living 209 in H3 cells with predominantly White versus predominantly Black or Pardo residents, 210 as well as of the population living in areas of the wealthiest and poorest income 211 quintiles. The daily social distancing index from hexagons were regressed on a set of 212 relative time dummies that indicated the number of days before and after the first NPI 213 introduction in São Paulo state. Hexagon-fixed effects controlled for unobserved time214 invariant determinants of social distancing, while day-fixed effects controlled for 215 temporal shocks common to all hexagons. We further included an additional time216 varying control variable, representing the number of days relative to the first confirmed 217 SARI case in each hexagon, and a dummy variable indicating the period of NPI 218 relaxation in each municipality. Sensitivity analyses were performed and discussed in 219 Supplementary Appendix A.

220 We employed a multinomial logistic regression to estimate the probability that 221 employed individuals would be working face-to-face, teleworking, or taking paid or 222 unpaid leave. Differences in the work status of individuals by race, education, and 
medRxiv preprint doi: https://doi.org/10.1101/2020.12.09.20246207; this version posted December 13, 2020. The copyright holder for this preprint (which was not certified by peer review) is the author/funder, who has granted medRxiv a license to display the preprint in perpetuity.

It is made available under a CC-BY-ND 4.0 International license .

223 occupation were calculated while controlling for age and sex. 35 groups of 224 employment occupations listed in the PNAD COVID-19 survey were aggregated to 225 ten SCO-08 1-digit occupational groups defined by the International Labour 226 Organisation. We further disaggregated health professionals and health technicians 227 (Supplementary Appendix A - Table A2).

\section{Comorbidities}

229 PNAD COVID-19 data was used to conduct a binomial logistic regression to estimate 230 the odds ratio of having at least one comorbidity, by race and education attainment 231 (pre-primary, primary, secondary, and tertiary), while controlling for age and sex for 232 São Paulo state. The comorbidities considered were chronic obstructive pulmonary 233 disease (COPD), diabetes, hypertension, or cardiovascular disease such as 234 myocardial infarction, angina or heart failure. Confidence intervals for the odds ratios 235 were calculated taking into account PNAD's complex sample design.

237 Results

238 Between March 1 and August 29, 2020, São Paulo state had the highest number of 239 SARI hospitalisations per 100000 habitants compared to all states in Brazil (figure 240 1A). A time series illustrating the number of SARI hospitalisations is presented in 241 figure 1B. During this time, 232540 patients were notified in the SIMI-SP database 242 (figure 1C), from which 230794 (99.2\%) had a confirmed COVID-19 diagnosis or were 243 diagnosed with SARI of unknown or missing aetiology. From these, 223455 were 244 hospitalised (98.4\%) or died without hospitalisation (1.6\%). From the non-hospitalised 245 cases, we only selected deaths; 54108 patients died, of which $52.5 \%$ were White, $24620.2 \%$ were Pardo, 6.13\% were Black, 1.96\% were Asian, 0.052\% were Indigenous 247 and $19 \cdot 6 \%$ did not have race information. We geocoded $178345(79 \cdot 8 \%)$ of all SARI 248 cases considered in our analyses with high accuracy at either street address, route, 249 or neighbourhood level without compromising personal privacy. 
medRxiv preprint doi: https://doi.org/10.1101/2020.12.09.20246207; this version posted December 13, 2020. The copyright holder for this preprint (which was not certified by peer review) is the author/funder, who has granted medRxiv a license to display the preprint in perpetuity.

It is made available under a CC-BY-ND 4.0 International license .

250 During the first month of the COVID-19 epidemic (March) in Brazil, hospitalised 251 patients were more likely to be White or Asian and come from census tracts with higher 252 income per capita (figure $2 \mathrm{~A}$ and $2 \mathrm{~B}$ ). During this period, people living in low-income 253 areas, compared to high-income areas, were less likely (OR: $0.44,95 \% \mathrm{Cl}: 0.42-$ 2540.46 ) to be hospitalised with SARI. This coincides with the early establishment of 255 COVID-19 and its first cases in higher-income travellers returning from overseas ${ }^{9,12}$.

256

257

258

259

260

261

262
A

B

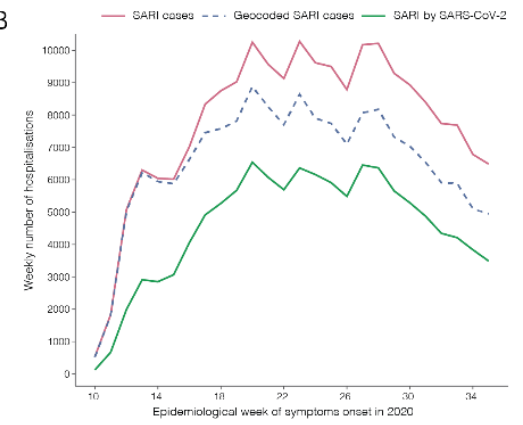

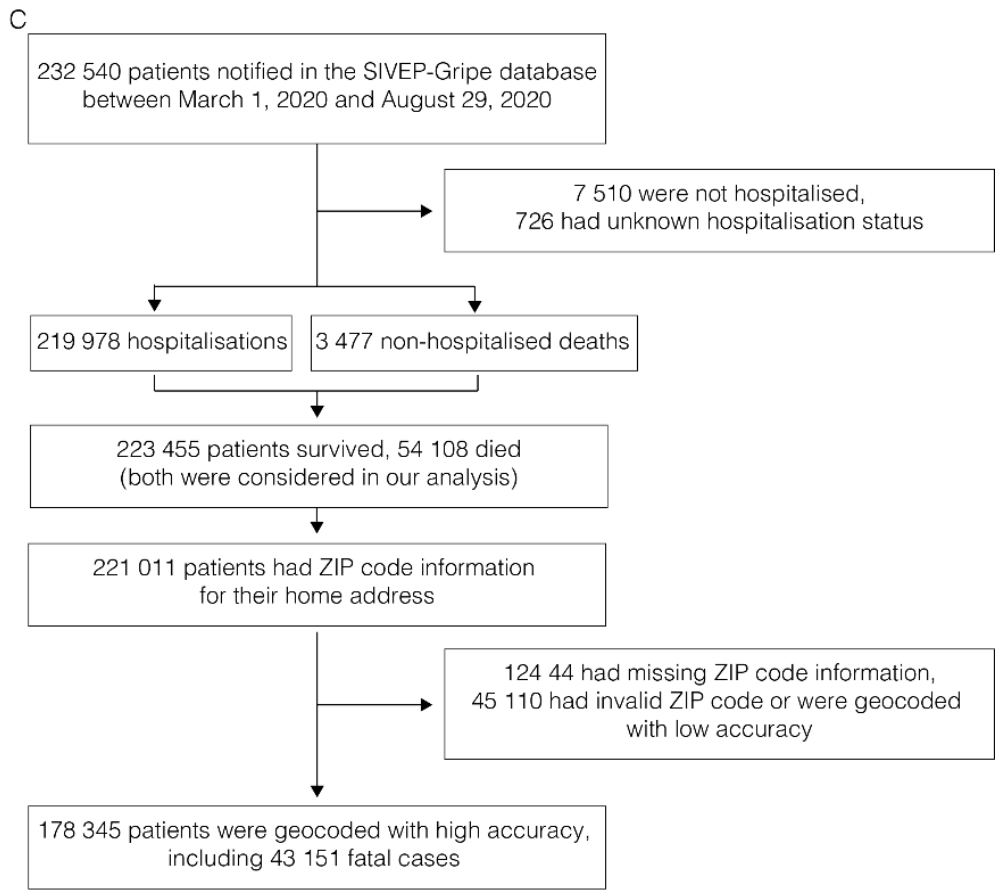

Figure 1. Number of SARI hospitalisations per 100000 habitants by state in Brazil between March 1 and August 29, 2020 (A). Number of SARI hospitalisations for the state of São Paulo and the greater metropolitan area of São Paulo (RMSP) by week of symptom onset (B). Flowchart of SIMI-SP data processing (Source: https://covid.saude.gov.br) (C).

263 As the epidemic progressed from April onwards, patients were also more likely to be 264 from low-income census tracts (April to July, OR: 1.08, 95\% Cl: 1.04-1.12), except 265 for August, when patients were less likely to be from low-income census tracts (OR: 266 0.95, 95\% Cl: 0.91 - 1.00). Similarly, Black Brazilians and Pardos became more likely 267 to be hospitalised with SARI than Whites (OR: 1.37, 95\% Cl: 1.32 - 1.41; OR: 1.23, $26895 \% \mathrm{Cl}: 1 \cdot 21-1 \cdot 25$, respectively), while Asians became the least likely to be 269 hospitalised (OR: $0.90,95 \% \mathrm{Cl}: 0.83-0.96)$. These results were further confirmed by 
medRxiv preprint doi: https://doi.org/10.1101/2020.12.09.20246207; this version posted December 13, 2020. The copyright holder for this preprint (which was not certified by peer review) is the author/funder, who has granted medRxiv a license to display the preprint in perpetuity.

It is made available under a CC-BY-ND 4.0 International license .

270 our seroprevalence findings, which showed that anti-SARS-CoV-2 antibodies were 271 highest in Black blood donors and those with low educational attainment across all 272 age groups (Supplementary Appendix B - figure S1).
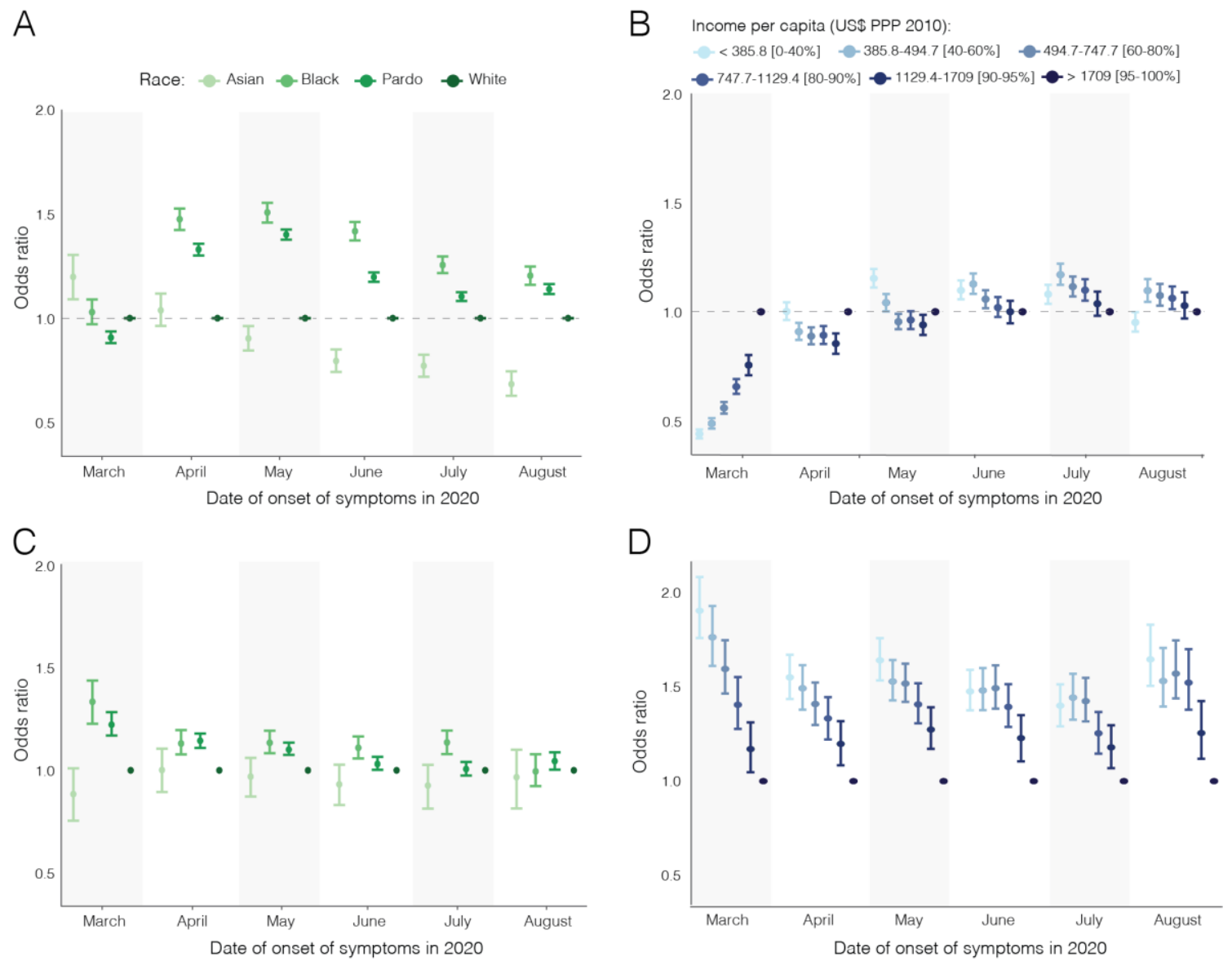

E

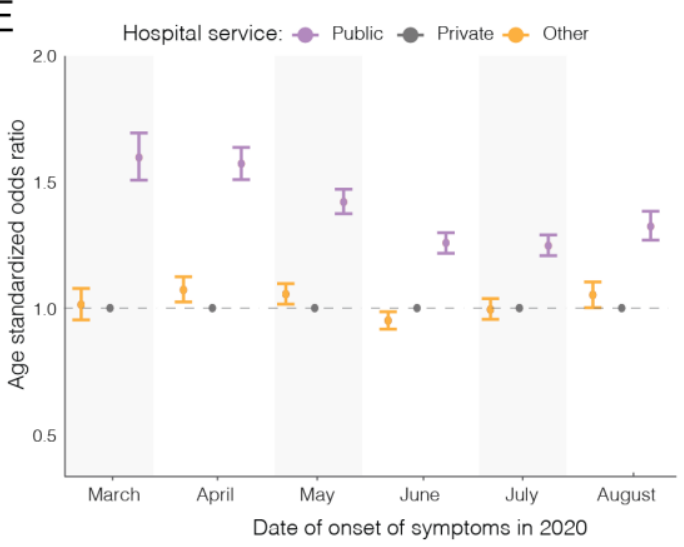

274 Figure 2. Age-standardised odds ratio (OR) for SARI hospitalisation by race (A) and 275 by income (B); Age-standardised OR of death among SARI cases by race (C) and 276 income (D); and Age-standardised OR of death among SARI cases by hospital type 277 for São Paulo state (E). PPP: Purchasing power parity. 
278 Once hospitalised, Black and Pardo patients were more likely to die from SARI than

279 White patients (OR: 1.14, 95\% Cl: $1.07-1 \cdot 21 ; 1.09,95 \% \mathrm{Cl}: 1.05-1 \cdot 13$, 280 respectively) (figure $2 \mathrm{C}$ ). This difference was more pronounced in March and was 281 reduced over time. We found that patients living in the poorest census tracts were 282 more likely to die from SARI compared to patients from the wealthiest tracts (OR: 1.60, $28395 \% \mathrm{Cl}: 1.48$ - 1.74) (figure 2D). Likewise, patients treated in public hospitals were 284 more likely to die than patients treated in private hospitals throughout the epidemic 285 (OR: 1.40, 95\% Cl: 1.34-1 -46) (figure 2E). Racial differences in the probability of death 286 decreased when considering only patients hospitalised at public health facilities but 287 persisted among patients in private facilities (Supplementary Appendix B - figure S2).

288 To understand the geographical variation in SARI hospitalisation, we predicted and 289 mapped the relative risk of SARI hospitalisation for São Paulo state by month via a 290 model with a spatial structure defined by human movement fluxes derived from 291 anonymised mobile phone data (figure 3A) and covariates related to socioeconomic 292 status (figure 3B). This is shown in figure 3C. We found a lower risk of hospitalisation 293 in municipalities with high income per capita (fixed effect $=-0.93,95 \% \mathrm{Cl}:-1 \cdot 17-$ $2940.69)$ and high proportion of adult residents with a primary education or lower $(-0.80$, $29595 \% \mathrm{Cl}:-1 \cdot 0--0 \cdot 60$ ). Municipalities with fewer nearby public health facilities were 296 also found to have lower risk of hospitalisation (-0.24, 95\% Cl: $-0.45--0.03)$. We also 297 found a higher risk of SARI hospitalisation in municipalities with higher population 298 density $(0 \cdot 24,95 \%$ credible interval: $0.04-0.44)$.

299

A

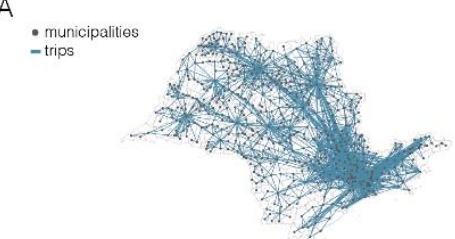

B

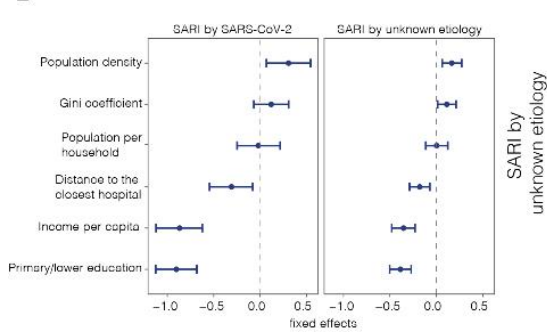

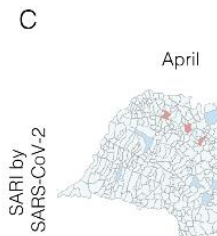$$
\text { the }
$$

$\longdiv { 2 0 0 \mathrm { kn } }$

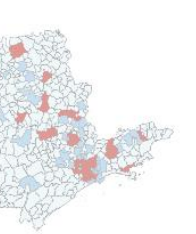

Posterior mean relative risk: $\square<0.5 \quad 0.5-1 \quad \square>1-2 \quad \square>2-3$

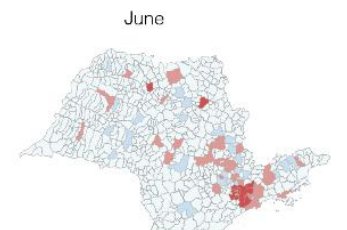

August

.


medRxiv preprint doi: https://doi.org/10.1101/2020.12.09.20246207; this version posted December 13, 2020. The copyright holder for this preprint (which was not certified by peer review) is the author/funder, who has granted medRxiv a license to display the preprint in perpetuity.

It is made available under a CC-BY-ND 4.0 International license .

301 Figure 3: Relative risk of SARI hospitalisation in the state of São Paulo at the 302 municipality level (A). Human movement between municipalities based on In-Loco 303 mobile phone data retrieved from March to August 2020 (B). Fixed effects and 95\% 304 credible intervals for socioeconomic covariates (C).

306 We found that over time, the risk of SARI hospitalisation increased particularly in 307 municipalities near and within the RMSP, where $70 \%$ of the SARI cases reported for 308 the state are concentrated (figure 4A). By mapping risk at the census tract level for 309 the RMSP, we detected increasing risk starting from São Paulo city (central region). 310 By June, almost all of the census tracts in and near the city centre were found to have 311 high relative risk, but this risk decreased by August.

313 Differential risk to SARI in the RMSP was also associated with daily mobility levels by 314 disadvantaged groups. Before the implementation of NPIs on March 13, mobility levels 315 were similar across all socioeconomic groups (figures 4B and 4C). However, 14 days 316 after the introduction of NPIs, isolation levels were 8.2\% (95\% Cl: 7.2\%-9.2\%) higher 317 in predominantly White areas compared to predominantly Black areas. Similarly, 27 318 days after the introduction of state-level NPIs, isolation levels were $11.2 \%$ (95\% Cl: $31910 \cdot 6 \%-11.9 \%)$ higher in the wealthiest than in the poorest areas. Overall, we 320 detected a decreasing trend in isolation levels over time, and the magnitude of the 321 differences in social isolation levels between areas with predominantly White and 322 Black populations decreased to only $4.4 \%(95 \% \mathrm{Cl}$ : $3 \cdot 3 \%-5 \cdot 5 \%) 151$ days after the 323 introduction of the NPIs (figure 4D). 
medRxiv preprint doi: https://doi.org/10.1101/2020.12.09.20246207; this version posted December 13, 2020. The copyright holder for this preprint (which was not certified by peer review) is the author/funder, who has granted medRxiv a license to display the preprint in perpetuity.

It is made available under a CC-BY-ND 4.0 International license .

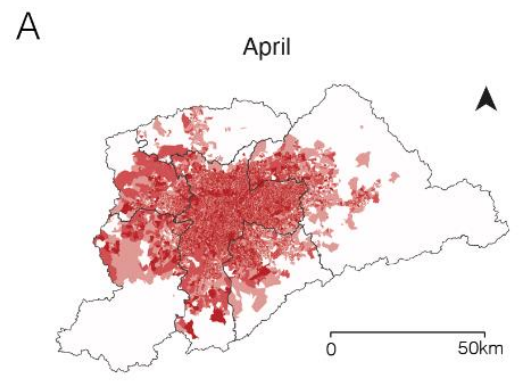

Posterior mean relative risk: $\square<0.5$

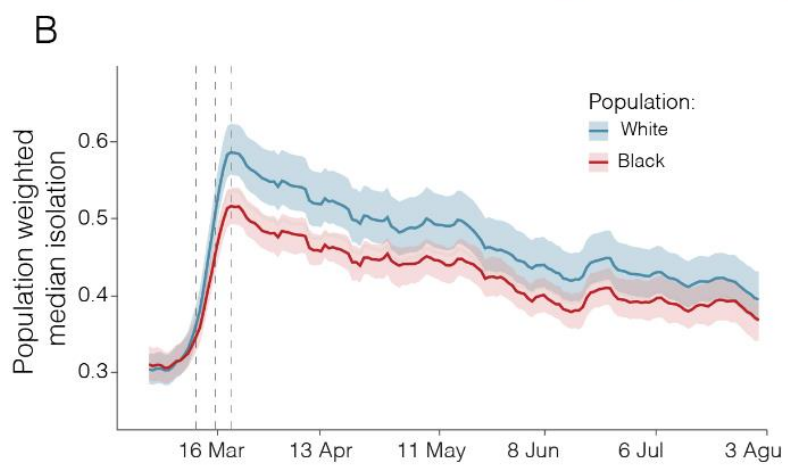

C

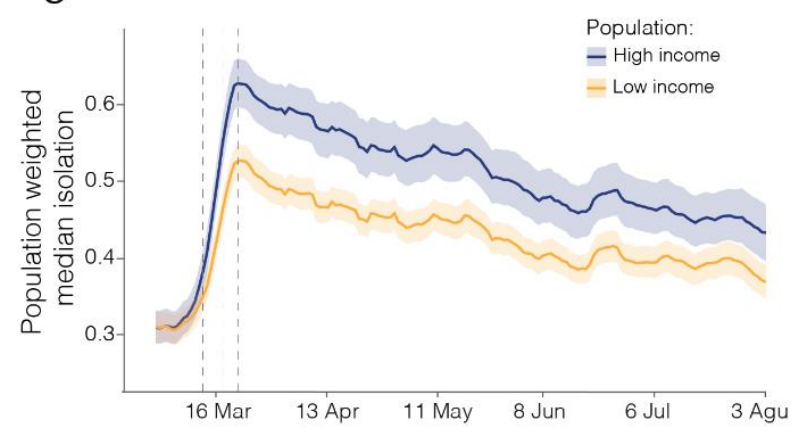

June

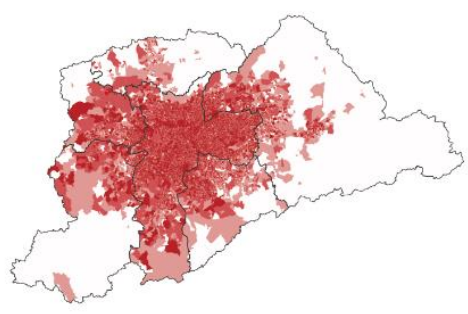

$>2-32$
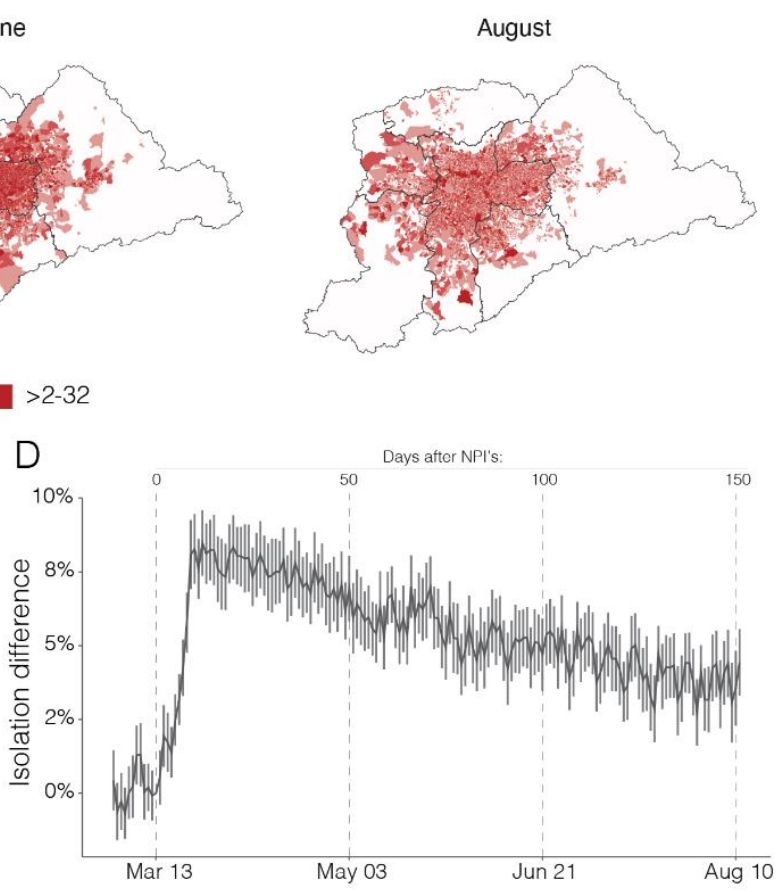

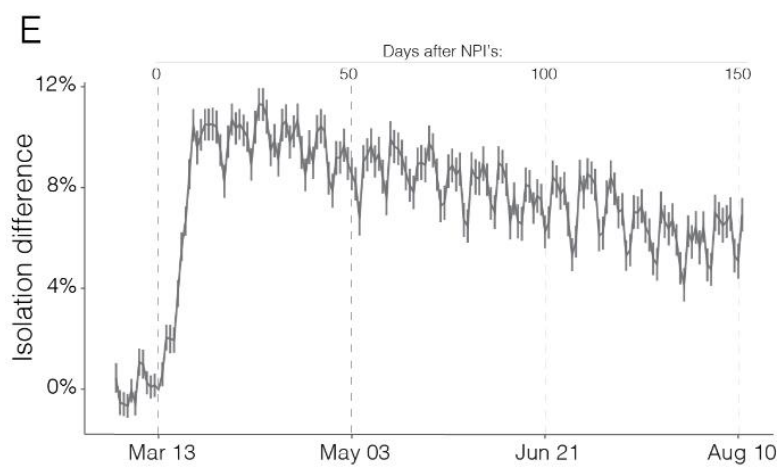

326

327

328

329

330

331

332

333

334

335

336

337

338

Figure 4. Relative risk of SARI hospitalisation for the RMSP (A). Seven-day moving average of daily median levels in social distancing by race (B) and income (C). Difference in daily social isolation by race $(D)$ and income $(E)$ after the introduction of NPIs. In panels (B) and (C), solid lines show population-weighted median isolation levels and shaded areas show population-weighted interquartile range (25\% - 75\%). Dashed vertical lines indicate the dates of NPIs that enabled school closure (March 13 was the state NPI) and non-essential activities (March 18 and 22, municipal and state NPIs, respectively).

Finally, we investigated the differential risk to SARI based on workers' position in the labour market using data from the PNAD COVID-19 survey. After the introduction of NPIs, workers employed in low-skilled jobs or essential services were more likely to keep working face-to-face than workers in professional or managerial positions 
339 (Supplementary Appendix B - figure S3). Workers with pre-primary education were 340 more likely to work in occupations that require in-person contact than workers with 341 tertiary education (Probability: 0.89, 95\% Cl: 0.87 - 0.90 compared to PR: $0.58,95 \%$ $342 \mathrm{Cl}: 0.57-0.60)$ and less likely to work in occupations that allow teleworking (PR: $3430.005,95 \% \mathrm{Cl}: 0.004-0.007$ versus PR: $0.3695 \% \mathrm{Cl}: 0.35-0.37$, respectively) 344 (figure 5A). When controlling for education and formal or informal employment, we 345 found no substantial difference between racial groups in the probability of working 346 face-to-face or teleworking (figure 5B).

347 We found that population groups at risk of death from SARI were also more likely to 348 have comorbidities. Compared to the population with tertiary education in São Paulo 349 state, individuals with primary education or lower are more likely to have one or more 350 comorbidities (OR: 1.36, 95\% Cl: $1 \cdot 27$ - 1.45) (figure 5C). Similarly, Black individuals 351 were also more likely to have one or more comorbidities than White individuals (OR: $3521 \cdot 29,95 \% \mathrm{Cl}: 1 \cdot 19-1 \cdot 39$ ) (figure 5D). Odds ratio estimates for each health condition 353 are summarised in Supplementary Appendix B - figure S4. 
medRxiv preprint doi: https://doi.org/10.1101/2020.12.09.20246207; this version posted December 13, 2020. The copyright holder for this preprint (which was not certified by peer review) is the author/funder, who has granted medRxiv a license to display the preprint in perpetuity.

It is made available under a CC-BY-ND 4.0 International license .
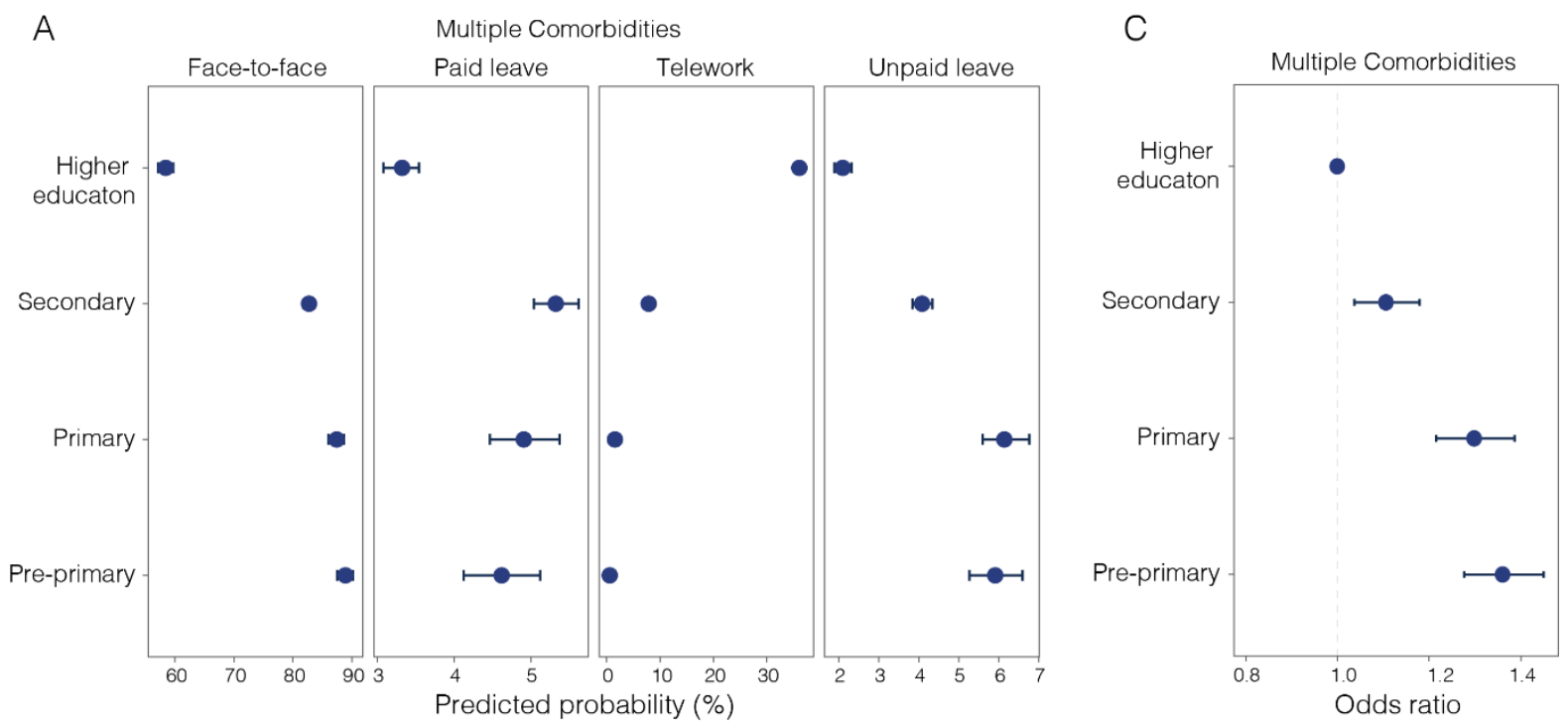

B

Multiple Comorbidities
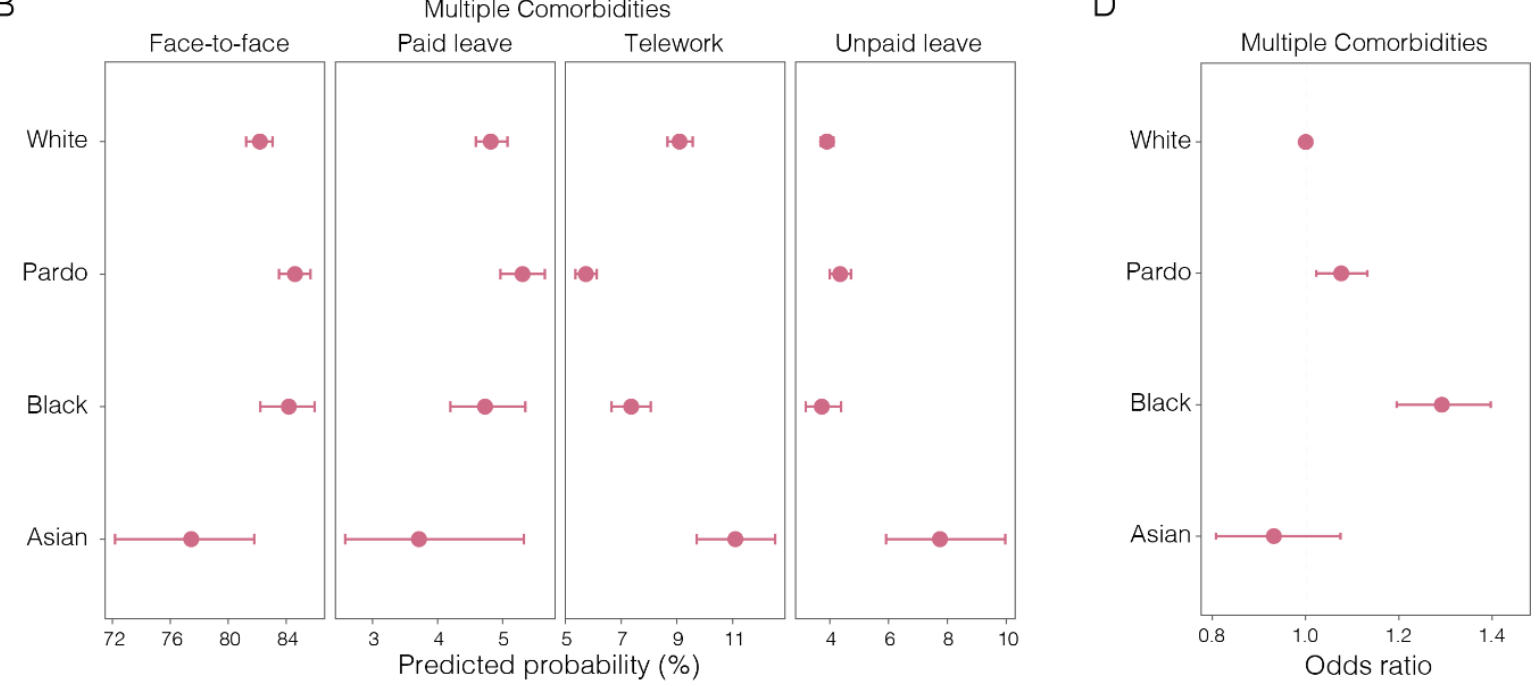

Figure 5: Probability of different working conditions by education attainment $(A)$ and race $(B)$. Odds ratio $(O R=1)$ of having multiple comorbidities: chronic obstructive pulmonary disease (COPD), diabetes, hypertension or cardiovascular disease such as infarction, angina, and heart failure by education attainment $(C)$ and race (D). 359 Horizontal lines show 95\% confidence intervals. Source: PNAD COVID-19 /IBGE 17, 360 July to September, 2020.

\section{Discussion}

363 Our study shows that disadvantaged hospitalised groups are disproportionately more

364 likely to die from SARI. We find that the differential health outcomes can be explained 365 by structural inequities linked to the incidence of comorbidities and to socioeconomic 
366 status, which limit the ability of these groups to socially isolate and reduce their access

367 to optimal health services.

369 Social and racial inequalities shape the risk of SARI hospitalisation and death. After 370 the initial phase of international imports in Brazil ${ }^{12}$, Black or Pardo Brazilians residing

371 in low-income areas were more likely to be hospitalised and die with SARI compared 372 to White individuals, which aligns with recent findings ${ }^{7}$. Our assessment of anti-SARS373 CoV-2 antibodies in blood donors categorised by demographic background further 374 confirms that Black Brazilians and those with lower socioeconomic status are 375 disproportionately exposed to COVID-19. While patients hospitalised in public health 376 facilities were more likely to die than those in private health facilities, racial inequalities 377 in death probability are attenuated when only considering patients within hospitals of 378 the same type, either public or private. Potential factors influencing this inequality 379 include higher comorbidities among poor Black patients and the lower access to private care among low-income individuals that are disproportionately Black.

We found higher hospitalisation risk for those living in municipalities with low income per capita and high population density compared to the rest of São Paulo state. These populations mainly reside in the RMSP, which contains nearly half of the population in São Paulo state and where bias in testing is evident in regions of lower socioeconomic status ${ }^{12}$ (Supplementary Appendix B - figure S5). The risk of SARI hospitalisation is particularly elevated in São Paulo city, where seroprevalence estimates from blood donors show that anti-SARS-CoV-2 antibodies were highest in older Black Brazilians and those with lower educational attainment.

We show that inequalities in the risk of SARI hospitalisation were partially explained 392 by differential mobility responses to social distancing guidelines, similar to the US ${ }^{22}$. 393 In wealthier and predominantly White neighbourhoods, people were able to isolate 394 faster and sustain isolation for long periods of time. Among the working population, 395 low-income and Black workers were less likely to receive a furlough from work or 396 telework. Due to systemic inequalities in education and the labour market, these 
397 groups are disproportionately employed in precarious job positions with no social 398 security and dependent on day-to-day income ${ }^{23}$, limiting their ability to reduce 399 mobility. Other important factors include the disadvantage of having multiple 400 comorbidities, which are more prevalent among Blacks and Pardos and those with 401 lower education.

402

403 Our study has limitations that may have underestimated the level of inequality. Firstly, 404 geocoding cases may have discarded patients from poor census tracts where 405 accuracy is limited 24 . Secondly, using data aggregated for various administrative 406 levels has inherent limitations due to ecological fallacy and the modifiable areal unit 407 problem ${ }^{25}$. Finally, the 2010 Brazilian population census and PNAD COVID-19 survey 408 may have limited the capture of socioeconomic changes in the last decade and 409 inclusion of extremely wealthy individuals ${ }^{26}$. Additionally, disadvantaged groups can 410 be underrepresented in health administrative records because of their lower access 411 to healthcare. Given that São Paulo is the wealthiest state and has the most robust 412 healthcare system in Brazil ${ }^{27}$, it is possible that the impact of inequalities is more 413 severe in other states.

415 Our findings on the difference in risk of SARI death reveal stark inequalities in access 416 to healthcare. Only $25 \%$ of Brazilians have access to private healthcare via health 417 insurance, reflecting how inequality in access to quality healthcare is largely driven by 418 income ${ }^{28}$. This leaves $75 \%$ of the population solely reliant on a chronically 419 underfunded public healthcare system, which highlights that disadvantaged 420 populations are more likely to be infected and deprived of care. Strengthening 421 healthcare access and its capacity will be critical for reducing health inequities during 422 this and forthcoming public health emergencies ${ }^{29}$.

424 Our findings on socioeconomic risk factors could help guide vaccine allocation in 425 diverse settings to achieve equitable access. Ensuring that disadvantaged groups, 426 especially those that have in-person occupations and live in crowded and deprived 427 areas receive vaccination will help prevent and slow down community transmission. 
428 While race is not a risk factor in itself, it is critical to consider systemic inequalities that

429 lead Black and Pardo communities to be overrepresented among low socioeconomic 430 groups, to have higher rates of severe COVID-19 infection, and comorbidities that 431 exacerbate their risk of death. Therefore, including disadvantaged populations among 432 priority groups for vaccination could help reduce health inequities instead of 433 exacerbating them ${ }^{30}$.

435 Our study highlights the need for additional research to comprehend the effects of 436 social and health inequalities during pandemics. Firstly, an assessment of the 437 inequality in access to quality care within public and private health facilities and its risk 438 factors is needed to better understand mortality in different hospital settings. Secondly, 439 our study shows that population response to NPIs can vary significantly based on 440 social circumstances, suggesting that future studies should also consider 441 socioeconomic aspects when evaluating the effectiveness of NPIs. Thirdly, more data 442 is needed on whether social safety net programs that are guaranteeing income for 443 disadvantaged groups during the pandemic (e.g., Brazil's emergency cash payment), 444 may have enabled people to reduce their mobility. Nevertheless, our study has shown 445 the impact of social inequities on COVID-19 hospitalisation and death, thus informing 446 future research and policies related to the health impacts of COVID-19 in Latin 447 America. 
medRxiv preprint doi: https://doi.org/10.1101/2020.12.09.20246207; this version posted December 13, 2020. The copyright holder for this preprint (which was not certified by peer review) is the author/funder, who has granted medRxiv a license to display the preprint in perpetuity.

It is made available under a CC-BY-ND 4.0 International license .

\section{Contributors}

450 SLL and RHMP conceived the research questions and designed the study. RHMP, 451 CAPJ, LE, PJHA, PSP, CKB, AASS, WMS, RJB, LFB, AM, CAN, SCF, and NAS 452 collected the epidemiological, socioeconomical, mobility, NPIs, seroprevalence, and 453 comorbidities data. SLL, RHMP, CAPJ, AEZ, LE, PJHA, CKB, RJB, and VN conducted 454 exploratory and statistical analysis and interpreted the results. SLL, RHMP, and CAPJ 455 wrote the manuscript. All authors read and revised the final manuscript.

\section{Acknowledgement}

458 SLL is supported by the Oxford Martin School and the Canadian Social Sciences and 459 Humanities Doctoral Fellowship. CAPJ is supported by Coordenação de 460 Aperfeiçoamento de Pessoal de Nível Superior - Brasil (CAPES) and Fundação 461 Faculdade de Medicina (FFM). AEZ is supported by The Oxford Martin Programme 462 on Pandemic Genomics. WMS is supported by the São Paulo Research Foundation, 463 Brazil (2017/13981-0 and 2019/24251-9). NRF is supported by a Wellcome Trust and 464 Royal Society Sir Henry Dale Fellowship (204311/Z/16/Z). 


\section{References}

1 Ahmed F, Ahmed N, Pissarides C, Stiglitz J. Why inequality could spread COVID19. Lancet Public Health 2020; 5: e240.

2 Walker PGT, Whittaker C, Watson OJ, et al. The impact of COVID-19 and strategies for mitigation and suppression in low- and middle-income countries. Science 2020; 369: 413-22.

3 Drefahl S, Wallace M, Mussino E, et al. A population-based cohort study of sociodemographic risk factors for COVID-19 deaths in Sweden. Nat Commun 2020; 11: 5097.

4 UK Office for National Statistics. Coronavirus (COVID-19) related deaths by ethnic group, England and Wales - Office for National Statistics. 2020 https://www.ons.gov.uk/peoplepopulationandcommunity/birthsdeathsandmarriage s/deaths/articles/coronavirusrelateddeathsbyethnicgroupenglandandwales/2marc h2020to10april2020 (accessed Nov 20, 2020).

5 Cummings MJ, Baldwin MR, Abrams D, et al. Epidemiology, clinical course, and outcomes of critically ill adults with COVID-19 in New York City: a prospective cohort study. The Lancet 2020; 395: 1763-70.

6 Pan D, Sze S, Minhas JS, et al. The impact of ethnicity on clinical outcomes in COVID-19: A systematic review. EClinicalMedicine 2020; 23: 100404.

7 Baqui P, Bica I, Marra V, Ercole A, Schaar M van der. Ethnic and regional variations in hospital mortality from COVID-19 in Brazil: a cross-sectional observational study. Lancet Glob Health 2020; 8: e1018-26.

8 Facundo A, Chancel, Lucas, Piketty,Thomas, Saez, Emmanuel, Zucman, Gabriel. World Inequality Report 2018. 2017.

9 Jesus JG de, Sacchi C, Candido D da S, et al. Importation and early local transmission of COVID-19 in Brazil, 2020. Rev Inst Med Trop São Paulo 2020; 62: e30.

10 Henriques CMP, Vasconcelos W, Henriques CMP, Vasconcelos W. Crises dentro da crise: respostas, incertezas e desencontros no combate à pandemia da Covid-19 no Brasil. Estud Av 2020; 34: 25-44.

11 Rezende LFM, Thome B, Schveitzer MC, et al. Adults at high-risk of severe coronavirus disease-2019 (Covid-19) in Brazil. Rev Saúde Pública 2020; 54. DOI:10.11606/s1518-8787.2020054002596.

12 de Souza WM, Buss LF, Candido D da S, et al. Epidemiological and clinical characteristics of the COVID-19 epidemic in Brazil. Nat Hum Behav 2020; 4: 85665. 
medRxiv preprint doi: https://doi.org/10.1101/2020.12.09.20246207; this version posted December $13,2020$. The copyright holder for this preprint (which was not certified by peer review) is the author/funder, who has granted medRxiv a license to display the preprint in perpetuity.

It is made available under a CC-BY-ND 4.0 International license .

503

504

505

506

507

508

509

510

511

512

513

514

515

516

517

518

519

520

521

522

523

524

525

526

527

528

529

530

531

532

533

534

535

536 537

13 Secretaria da saúde do estado de São Paulo. SIMI-SP: Pacientes internados por Síndrome Respiratória Aguda

Grave https://www.saopaulo.sp.gov.br/planosp/simi/ (accessed Oct 25, 2020).

14 Niquini RP, Lana RM, Pacheco AG, et al. SRAG por COVID-19 no Brasil: descrição e comparação de características demográficas e comorbidades com SRAG por influenza e com a população geral. Cad Saúde Pública 2020; 36: e00149420.

15 Hasell J, Mathieu E, Beltekian D, et al. A cross-country database of COVID-19 testing. Sci Data 2020; 7: 345.

16 Telles E, Paschel T. Who Is Black, White, or Mixed Race? How Skin Color, Status, and Nation Shape Racial Classification in Latin America. Am J Sociol 2014; 120: 864-907.

17 IBGE - Instituto Brasileiro de Geografia e Estatística (2020). Pesquisa Nacional por Amostra de Domicílios Contínua (PNAD) COVID-19. Microdados. .

18 Peixoto PS, Marcondes D, Peixoto C, Oliva SM. Modeling future spread of infections via mobile geolocation data and population dynamics. An application to COVID-19 in Brazil. PLOS ONE 2020; 15: e0235732.

19 De Souza Santos AA, Da Silva Cândido D, Marciel De Souza W, et al. SARSCoV-2 non-pharmaceutical interventions in Brazilian municipalities. 2020; : 1046406 bytes.

20 Buss LF, Prete CA, Abrahim CMM, et al. Three-quarters attack rate of SARSCoV-2 in the Brazilian Amazon during a largely unmitigated epidemic. Science 2020; published online Dec 8. DOI:10.1126/science.abe9728.

21 Weill JA, Stigler M, Deschenes O, Springborn MR. Social distancing responses to COVID-19 emergency declarations strongly differentiated by income. Proc Natl Acad Sci 2020; 117: 19658-60.

22 Chang S, Pierson E, Koh PW, et al. Mobility network models of COVID-19 explain inequities and inform reopening. Nature 2020; : 1-8.

23 Lustig N, Pabon VM, Sanz F, Younger SD. The Impact of COVID-19 Lockdowns and Expanded Social Assistance on Inequality, Poverty and Mobility in Argentina, Brazil, Colombia and Mexico. ECINEQ, Society for the Study of Economic Inequality, 2020 https://ideas.repec.org/p/inq/inqwps/ecineq2020-558.html (accessed Nov 20, 2020).

24 Giest S, Samuels A. 'For good measure': data gaps in a big data world. Policy Sci 2020; 53: 559-69. 
medRxiv preprint doi: https://doi.org/10.1101/2020.12.09.20246207; this version posted December 13, 2020. The copyright holder for this preprint (which was not certified by peer review) is the author/funder, who has granted medRxiv a license to display the preprint in perpetuity.

It is made available under a CC-BY-ND 4.0 International license .

53825 Duranton G, Overman HG. Testing for Localization Using Micro-Geographic 539 Data. Rev Econ Stud 2005; 72: 1077-106.

54026 Souza PHGF de. A distribuição de renda nas pesquisas domiciliares brasileiras: 541 harmonização e comparação entre Censos, PNADs e POFs. Rev Bras Estud Popul 542 2015; 32: 165-88.

54327 Paim J, Travassos C, Almeida C, Bahia L, Macinko J. The Brazilian health 544 system: history, advances, and challenges. The Lancet 2011; 377: 1778-97.

54528 Nogueira Avelar e Silva R, Russo G, Matijasevich A, Scheffer M. Covid-19 in 546 Brazil has exposed socio-economic inequalities and underfunding of its public 547 health system. The BMJ. 2020; published online June 19. 548 https://blogs.bmj.com/bmj/2020/06/19/covid-19-in-brazil-has-exposed-deeply-

549 rooted-socio-economic-inequalities-and-chronic-underfunding-of-its-public-health550 system/ (accessed Nov 20, 2020).

55129 Castro MC, Carvalho LR de, Chin T, et al. Demand for hospitalization services 552 for COVID-19 patients in Brazil. medRxiv 2020; : 2020.03.30.20047662.

55330 Emanuel EJ, Persad G, Kern A, et al. An ethical framework for global vaccine 554 allocation. Science 2020; 369: 1309-12. 